\title{
Preoxidation and Activation of the Lignin Char: Carbonization and Oxidation Procedures
}

\author{
Saloua Sebbahi, ${ }^{1}$ Adnane Ahmido, ${ }^{1}$ Fatima Kifani-Sahban, ${ }^{2}$ \\ Souad El Hajjaji, ${ }^{1}$ and André Zoulalian ${ }^{3}$ \\ ${ }^{1}$ Spectroscopy, Molecular Modeling, Materials and Environment Laboratory, Department of Chemistry, \\ Faculty of Sciences, Mohammed V University of Rabat, BP 1014, Rabat, Morocco \\ ${ }^{2}$ Laboratory of Thermodynamic and Energetic, Physical Department, Faculty of Sciences BP 1014, Rabat, Morocco \\ ${ }^{3}$ LERMAB, Team Process Engineering, Henri Poincaré University (Nancy 1), BP 239, Nancy Cedex, France
}

Correspondence should be addressed to Souad El Hajjaji; selhajjaji@hotmail.com

Received 29 August 2014; Revised 29 November 2014; Accepted 9 December 2014; Published 31 December 2014

Academic Editor: Yuanxin Zhou

Copyright (C) 2014 Saloua Sebbahi et al. This is an open access article distributed under the Creative Commons Attribution License, which permits unrestricted use, distribution, and reproduction in any medium, provided the original work is properly cited.

\begin{abstract}
A comprehensive process of pretreatment and oxidation of lignin char was developed to optimize the production of activated carbon. The lignin char was obtained by carbonization of lignin under nitrogen at $600^{\circ} \mathrm{C}$ for 2 hours. The optimum time and temperature used to oxidize the char without destruction were, respectively, 6 hours and $245^{\circ} \mathrm{C}$. The oxygen improves the reactivity of the sample in $\mathrm{CO}_{2}$ and evolved the sample of a thermoplastic behaviour to a thermosetting behaviour. The oxygenation in air of the lignin char does not change the mode of deformation acquired by the material during the carbonization. The preoxidized coal reacts more than the nonoxidized coal during the $\mathrm{CO}_{2}$ activation, whereas the reduction in volume in the first case is smaller than in the second. The preoxidized and then activated carbon shows the formation and the development of microporosity at the expense of macroporosity. This microstructure is one of the main characteristics of activated carbon, which can be used as adsorbent for different pollutants.
\end{abstract}

\section{Introduction}

The activated carbon can be prepared from organic substances of various origins. The physical activation, which consists in carbonizing the organic matter and to gasify the char, is one of the methods to prepare the activated carbon. During their carbonization, the majority of the organic substances acquire, in the case of a plastic deformation, thermomechanical characteristics and physical properties that confer thermal resistance to coals during their gasification.

Fossil coals are most stable thermically and their activation requires relatively high temperatures [1]. It would seem, according to the literature, that the reoxygenation of fossil coals makes it possible to reduce their thermal resistance and consequently to improve their reactivity [2-6]. Oxidation in air of the fossil coals is a fundamental stage in the preparation of the activated carbon. The operation consists in treating coal in air at temperatures lower than $400^{\circ} \mathrm{C}[7,8]$. The literature specifies that the pretreatment acts on the physical properties in particular on the thermoplasticity [9-14], on the chemical composition [15-20], and on the porous structure [21-26].

The reoxygenation is also applied to coals of vegetable origin $[15,20,27-29]$. Some work was interested in carrying out the pretreatment before or after carbonization. According to Fernandez Ibañez [27], the reactivity of coal during the gasification is better when the preoxidation is carried out before carbonization of the olive cores and the apple pulp. On the other hand, our work on wood [28] showed that oxygenation is more interesting after carbonization.

As it is the case of some fossil coals [16], lignin undergoes a plastic deformation by crazing during its carbonization giving it a high thermal stability [30]. The aim of this work is to study the effect of the pretreatment in air on the thermal stability, on the physicochemical and physical characteristics of the lignin char, and on the reactivity of oxidized coal during the gasification. The microstructure of preoxidized and then activated carbon will be presented. 
TABLE 1: Elemental analysis of the lignin char.

\begin{tabular}{llll}
\hline$\% \mathrm{C}$ & $\% \mathrm{H}$ & $\% \mathrm{O}$ & $\% \mathrm{~N}$ \\
\hline 75.76 & 2.16 & 15.29 & 0.35 \\
\hline
\end{tabular}

\section{Experimental Part}

2.1. Characteristics of Lignin Char. Commercial lignin powder was used (Aldrich, France) [30, 31]. The lignin char was obtained after carbonization. The carbonization of lignin was carried out in a tubular furnace under flowing nitrogen of $30 \mathrm{~cm}^{3} / \mathrm{min}$ at a heating rate of $10^{\circ} \mathrm{C} / \mathrm{min}$. The temperature of carbonization was of $600^{\circ} \mathrm{C}$ and the soaking time of the carbonaceous residue at this temperature was $2 \mathrm{~h}$. The coal thus prepared was called CL600. The elemental analysis of the lignin char was given in Table 1.

2.2. Preoxidation Procedure. The samples of CL600 were preoxidized in the furnace under $24 \mathrm{~cm}^{3} / \mathrm{min}$ airflow. The temperature of preoxidation (noted $T_{\mathrm{po}}$ ) varied from 60 to $300^{\circ} \mathrm{C}$ and the duration of the pretreatment (noted $t_{\text {po }}$ ) varied from three to 24 hours.

2.3. Activation Procedure. The samples of CL600 preoxidized or not were gasified in the presence of $24 \mathrm{~cm}^{3} / \mathrm{min}$ of $\mathrm{CO}_{2}$ flow. $100 \mathrm{mg}$ of the sample was heated under nitrogen up to the temperature of activation. Once the activation temperature was reached and remained constant, the nitrogen was stopped and $\mathrm{CO}_{2}$ was introduced into the furnace. The domain of activation temperatures was between 600 and $900^{\circ} \mathrm{C}$. At the end of the reaction, cooling was carried out under nitrogen. The degree of activation called "burn-off" and noted $\mathrm{BO}$ was evaluated by the following relation:

$$
\% \mathrm{BO}=\frac{m_{c}-m_{\mathrm{ac}}}{m_{c}} \times 100,
$$

where $m_{c}$ is coal mass before activation and $m_{\mathrm{ac}}$ is coal mass after activation.

2.4. Characterization Methods. Morphological analysis of samples was performed by scanning electron microscopy (SEM), GEOL JSM T330, at the Department of Physics of the Faculty of Sciences, Rabat, Morocco.

The surface area was determined by nitrogen $\left(\mathrm{N}_{2}\right)$ adsorption-desorption isotherms at $77 \mathrm{~K}$ using an automated gas sorption system "Micrometrics ASAP 2010" instrument. The degasification of the samples was carried out at $250^{\circ} \mathrm{C}$ during two hours under a mixture containing helium $70 \%$ and nitrogen $30 \%$. The specific surface area was calculated by the Brunauer-Emmett-Teller (BET) method.

2.5. Dimensional Variations Measurements. The measurements of the dimensional variations of the lignin char samples during the preoxidation and activation were made on pastilles, under the same conditions to those used for preoxidation and activation of powder samples. The samples dimensions were measured with $1 / 100 \mathrm{~mm}$ of precision in

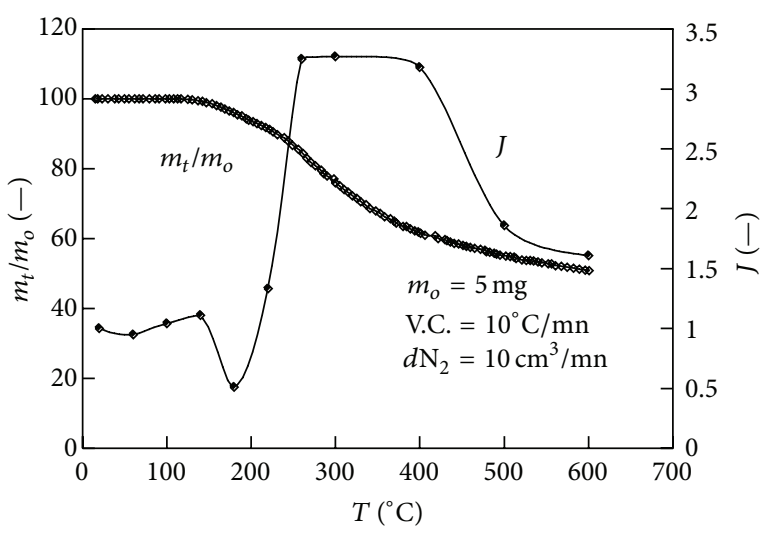

FIGURE 1: Effect of temperature on the mass and on the deformation Jacobian of lignin.

the principal directions before and after treatment. The total deformation corresponds to the volume variation of a material. This variation can, in general, be represented by Jacobian of the transformation (noted $J$ ) $[30,31]$. Jacobian was the ratio of the sample volume $(V)$ to the initial volume $\left(V_{o}\right)$. In the mechanics of the continued mediums, Jacobian was as follows:

$$
\begin{gathered}
J=\frac{V}{V_{o}}, \\
J=1+\operatorname{div} \vec{u}, \\
J=1+\varepsilon_{1}+\varepsilon_{2}+\varepsilon_{3},
\end{gathered}
$$

where $\vec{u}$ was the vector displacement and $\varepsilon_{1}, \varepsilon_{2}$, and $\varepsilon_{3}$ were the deformations in the principal directions of the sample.

\section{Results and Discussion}

3.1. Mass Loss and Dimensional Variations during the Carbonization. The mass loss and the dimensional variations of the lignin according to the temperature were given in Figure 1. The result shows that the lignin begins to decompose at $180^{\circ} \mathrm{C}$ and the percentage of the char at $600^{\circ} \mathrm{C}$ is about $50 \%$. The plot of the Jacobian $J$ of the transformation shows four deformation zones. The first, in the range from 140 to $180^{\circ} \mathrm{C}$, shows a shrinkage; the second, in the range from 180 to $260^{\circ} \mathrm{C}$, shows a dilatation which peaked at $260^{\circ} \mathrm{C}$. Beyond this temperature and up to $350^{\circ} \mathrm{C}$, the Jacobian keeps almost constant. In the last step, between 350 and $600^{\circ} \mathrm{C}$, the Jacobian decreases, resulting in a narrowing; therefore, the lignin undergoes a major dilatation. At $260^{\circ} \mathrm{C}$, the volume is four times higher than its initial volume. According to Friedrich [32], any increase of solid volume expresses a plastic deformation by cavitations. Forming the plastic phase slows degradation process and transforms the substance into a stable form [33-39].

3.2. Mass Loss and Elemental Analysis during the Preoxidation. Figure 2 shows the plot of mass loss of the lignin char according to the temperature of preoxidation. We noticed 


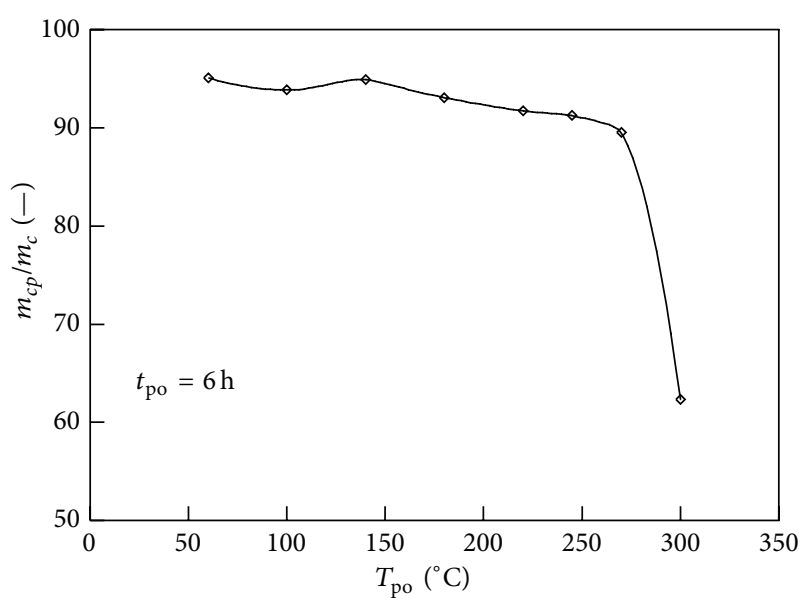

Figure 2: Mass loss of CL600 during preoxidation.

an initial weight loss followed by a resumption of mass between 60 and $140^{\circ} \mathrm{C}$. Up to $140^{\circ} \mathrm{C}$, two distinct zones were observed in which the mass loss decreases according to the temperature. The loss is about $5 \%$ between 140 and $270^{\circ} \mathrm{C}$ and $30 \%$ between $270^{\circ} \mathrm{C}$ and $300^{\circ} \mathrm{C}$. As the objective of the preoxidation was the reoxygenation of the substance without destruction, the preoxidation temperature of lignin char must be lower than $270^{\circ} \mathrm{C}$. Thus, the temperature selected to carry out the preoxidation of the lignin char was fixed at $245^{\circ} \mathrm{C}$.

The elemental analysis of the preoxidized sample at temperature below $270^{\circ} \mathrm{C}$ was given in Figure 3. The shape of the carbon content plot (Figure 3(a)) as a function of the preoxidation temperature is similar to the mass loss plot while the oxygen content (Figure 3(a)) moves in the opposite direction. At $140^{\circ} \mathrm{C}$, corresponding to weight gain (Figure 2), the carbon content is high while that of oxygen and hydrogen (Figure 3(b)) is low in comparison with the other samples. The decrease in the oxygen content and hydrogen is due to the dehydration that occurs by the departure of water molecules. Up to $140^{\circ} \mathrm{C}$, the carbon content decreases with the temperature of preoxidation while that of oxygen and hydrogen increases. This can be explained by a partial oxidation of coal with more oxygen scavenging.

The evolution of the mass loss of the samples preoxidized at $140^{\circ} \mathrm{C}$ and $245^{\circ} \mathrm{C}$ according to the preoxidation duration was represented in Figure 4. The results indicate that the loss of mass of the samples at $140^{\circ} \mathrm{C}$ is practically insensitive at oxidation time up to 9 hours and does not exceed $8 \%$ after 40 hours of reaction. On the other hand, at $245^{\circ} \mathrm{C}$, the loss exceeds $10 \%$ at the end of 9 hours of oxidation in air. For these two temperatures, the pretreatment time retained was 6 hours.

Our results are in good agreement with those of Pis et al. [9], which also noted that the mass of coal changes during the pretreatment in air and depends on the time and the temperature of pretreatment. The change in the mass [9] could be attributed to two processes which can take place separately or simultaneously. The first related to the fixing of oxygen inducing the increase in mass. The second is attributed to the elimination of the gaseous products, such
TABLE 2: Specific surface area (SS).

\begin{tabular}{lc}
\hline Sample & $\mathrm{SS}\left(\mathrm{m}^{2} / \mathrm{g}\right)$ \\
\hline CL600 & 30.8 \\
CL600 $\left(700^{\circ} \mathrm{C}, 1 \mathrm{~h}, \mathrm{CO}_{2}\right)$ & 394.26 \\
CL600 $\left(245^{\circ} \mathrm{C}, 6 \mathrm{~h}\right.$, air $)\left(700^{\circ} \mathrm{C}, 1 \mathrm{~h}, \mathrm{CO}_{2}\right)$ & 529.87 \\
\hline
\end{tabular}

as the carbon dioxide, the carbon monoxide, and the steam water that leaded to the loss of mass.

3.3. Yield of the Activation. The degree of activation of the samples pretreated according to the temperature of preoxidation was given in Figure 5.

Figure 5 shows that the $\mathrm{BO}$ of the preoxidized samples decreases between $60^{\circ} \mathrm{C}$ and $140^{\circ} \mathrm{C}$ and then increases. This indicates that oxygenation has an effect on the gasification only up to the temperature of $140^{\circ} \mathrm{C}$, result corroborated by the elemental analysis (Figure 3 ) and by the microscopic analysis. The reactivity of different substances like the anthracite [3], the phenolic resin fiber [7], the bituminous coal [8], and the petroleum coke [26] was improved when they have been preoxidized before gasification.

3.4. Specific Surface Area of the Activâts. Table 2 summarizes the values of specific surface areas of CL600, activated CL600, and preoxidized and activated CL600. The results show that the reoxygenation of the char prior activation significantly improves the surface area of the sample.

One of the main characteristics of the activated carbon is having a large surface area. According to previous work $[4,6,9,10,16]$, the specific surface area of preoxidized coals was higher than that of nonoxidized. This behaviour has been explained $[16,40-42]$ by the formation of the crosslinking between the macromolecules of coal and connections supported by the oxygen contribution. Pis et al. [9] indicate that oxidation opens the pores and widens them which involve the increase of specific surface area.

3.5. Dimensional Variations. The evolution of the dimensional variations of the samples during the reoxygenation and during the activation was represented in Figure 6. The Jacobian of the reoxygenation $J_{\mathrm{po}}$ (line 1) as that of activation $J_{\text {act }}$ (line 2) indicates that the material volume increases. Moreover, this evolution is similar to that of ratio $\mathrm{O} / \mathrm{C}$ (Figure 7).

Overall, dimensions of the oxidized and then activated sample are lower than those of the oxidized sample. Moreover, in both cases, the sample volume increases up to $140^{\circ} \mathrm{C}$. However, the increase in volume is more significant during activation than during oxygenation. The weak increase in volume of the substance during oxygenation could be explained by the only rearrangements caused by the oxygen contribution; the effects of the temperature have no major consequences since the pretreatment is carried out at low temperatures. On the other hand, during activation, the high temperature seems to induce the rearrangements caused by the oxygen contribution and to lead to a significant increase in volume between $140^{\circ} \mathrm{C}$ and $245^{\circ} \mathrm{C}$. 


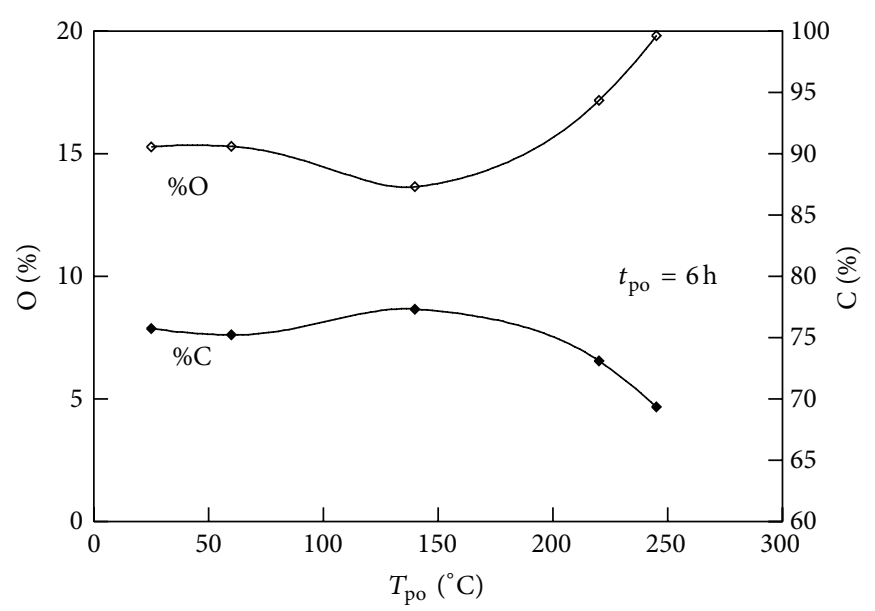

(a)

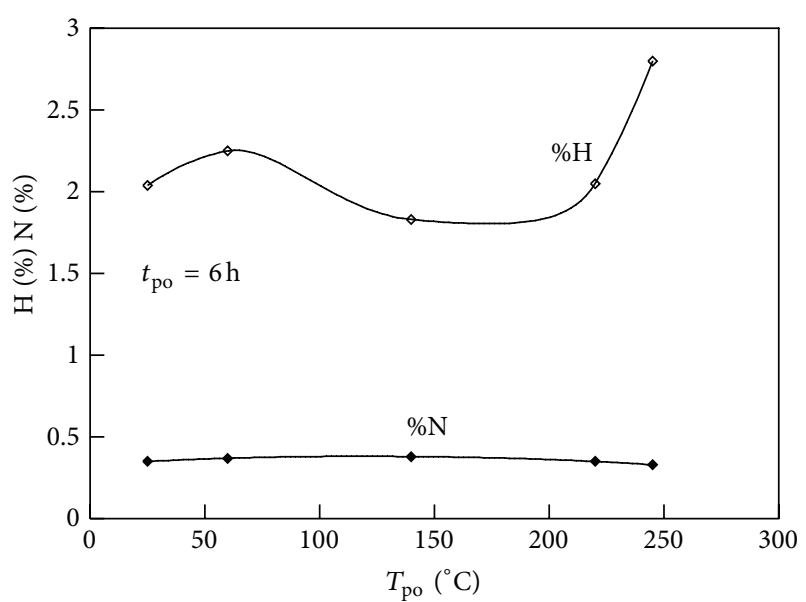

(b)

FIgURE 3: Elemental analysis of preoxidized char.

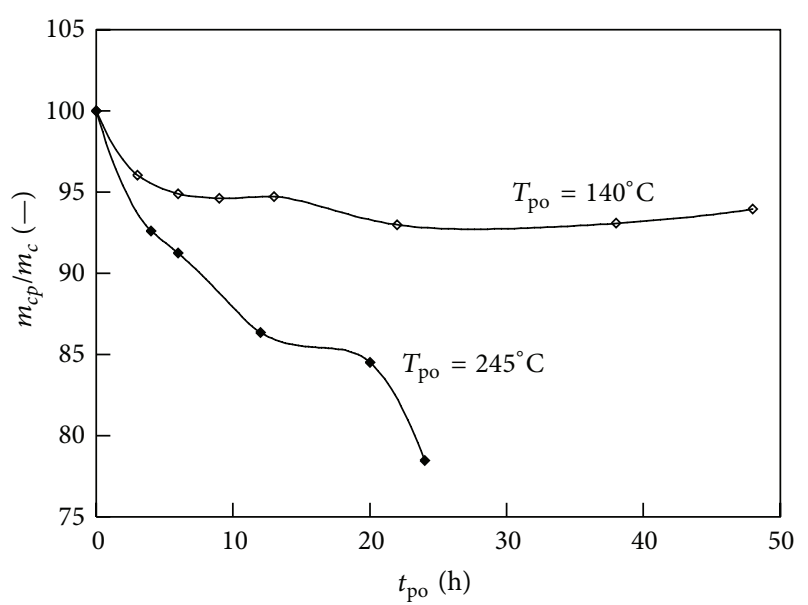

FIGURE 4: Effect of preoxidation time on mass of char.

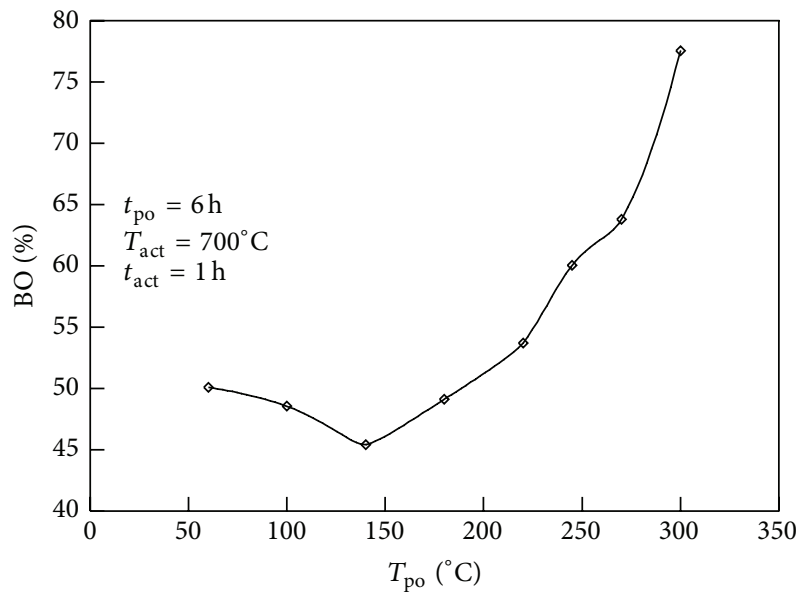

FIGURE 5: Yield of activation according to preoxidation temperature.

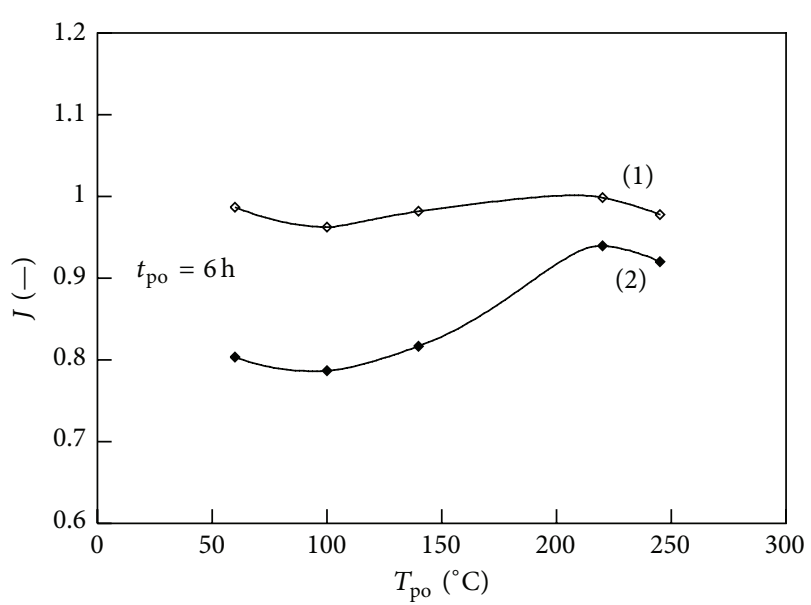

FIGURE 6: Jacobian of transformation according to preoxidation temperature. (1) $J_{\mathrm{po}}$. (2) $J_{\text {act }}$, sample preoxidized and activated at $700^{\circ} \mathrm{C}$ in 1 hour.

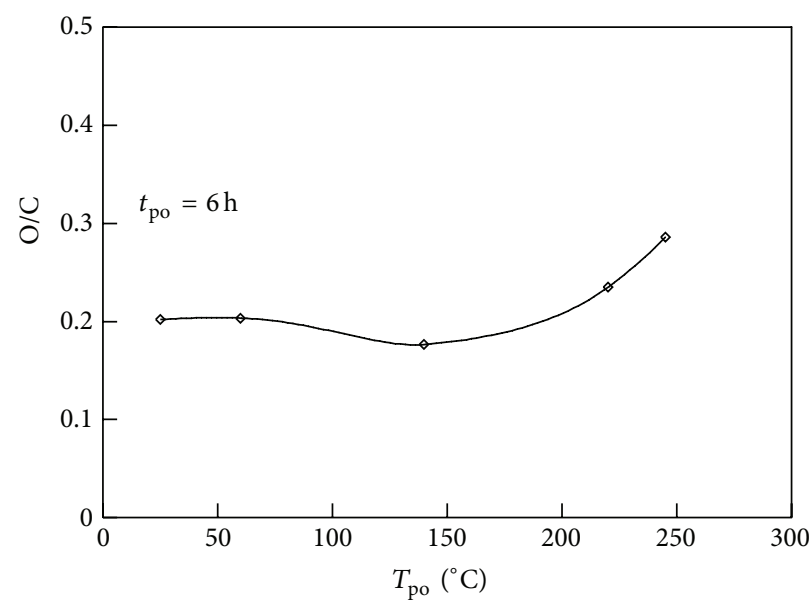

Figure 7: Ratio O/C in function of preoxidation temperature. 

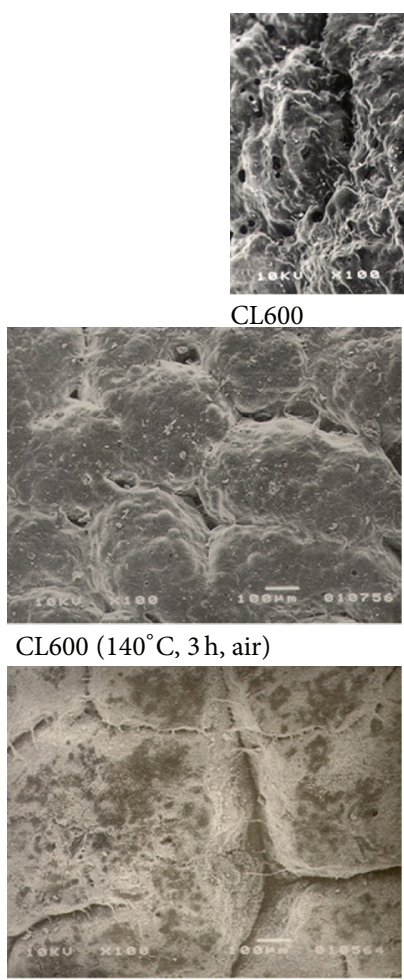

$\operatorname{CL600}\left(140^{\circ} \mathrm{C}, 6 \mathrm{~h}\right.$, air $)$
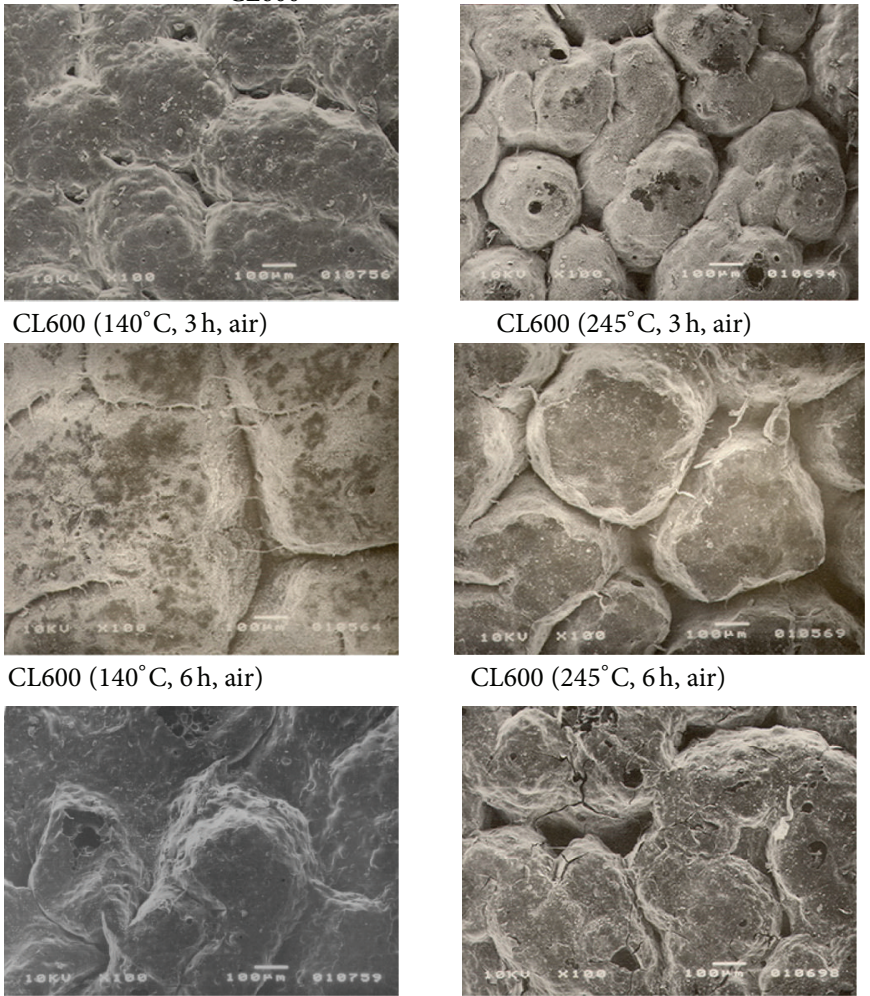

CL600 $\left(245^{\circ} \mathrm{C}, 3 \mathrm{~h}\right.$, air $)$

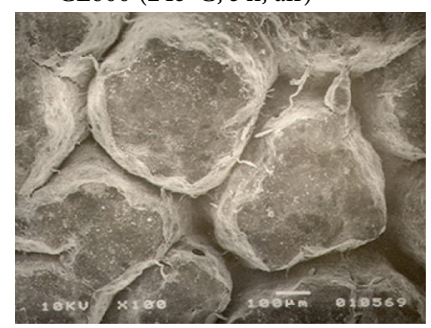

CL600 $\left(245^{\circ} \mathrm{C}, 6 \mathrm{~h}\right.$, air $)$

CL600 $\left(140^{\circ} \mathrm{C}, 9 \mathrm{~h}\right.$, air $)$
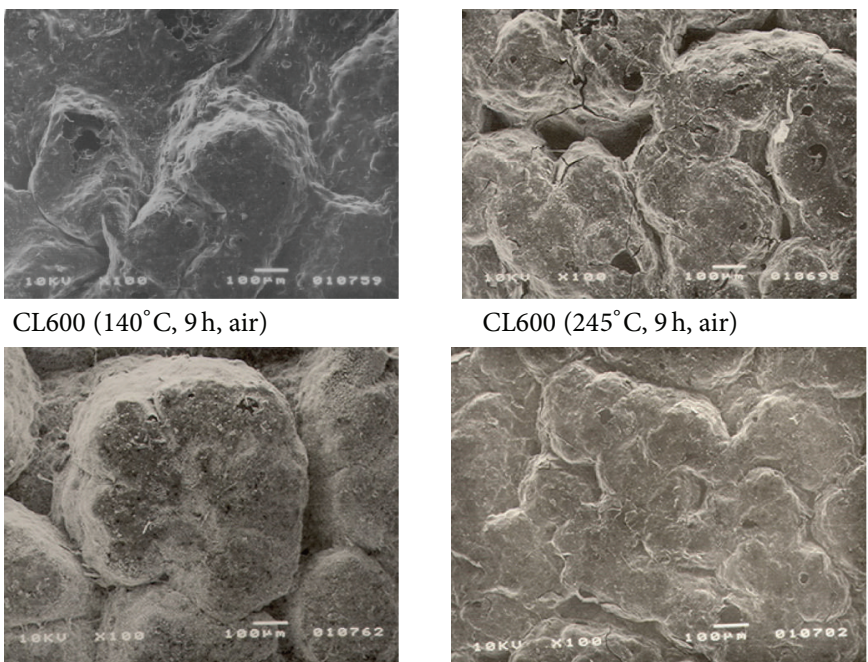

CL600 $\left(245^{\circ} \mathrm{C}, 9 \mathrm{~h}\right.$, air $)$

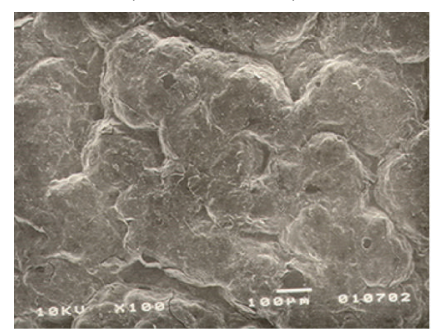

CL600 $\left(140^{\circ} \mathrm{C}, 13 \mathrm{~h}\right.$, air $)$

CL600 $\left(245^{\circ} \mathrm{C}, 13 \mathrm{~h}\right.$, air $)$

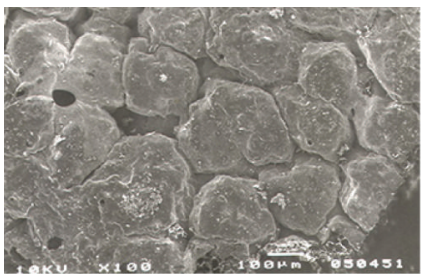

CL600 $\left(245^{\circ} \mathrm{C}, 24 \mathrm{~h}\right.$, air

FIGURE 8: Micrographs of external part of samples after pretreatment in air at different temperature and treatment time. 


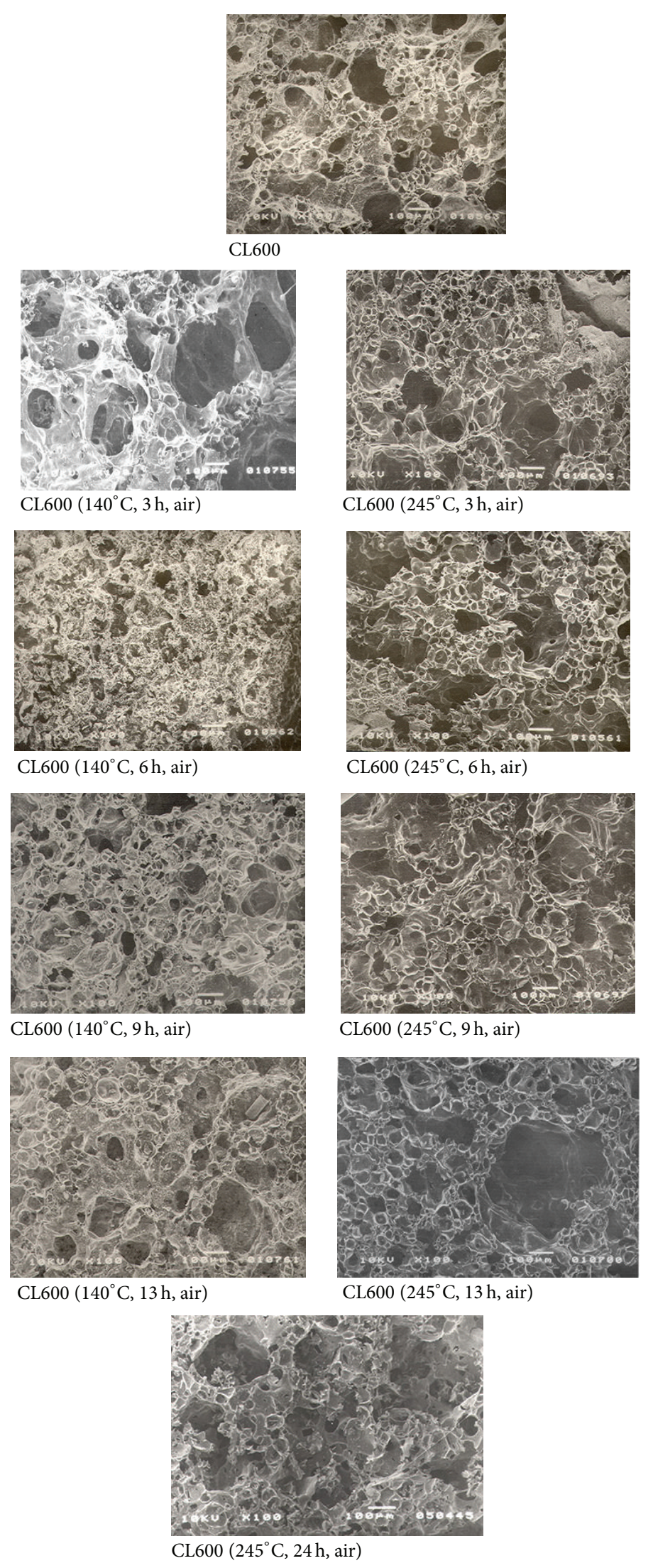

FIGURE 9: Micrographs of internal part of samples after pretreatment in air at different temperature and treatment time. 


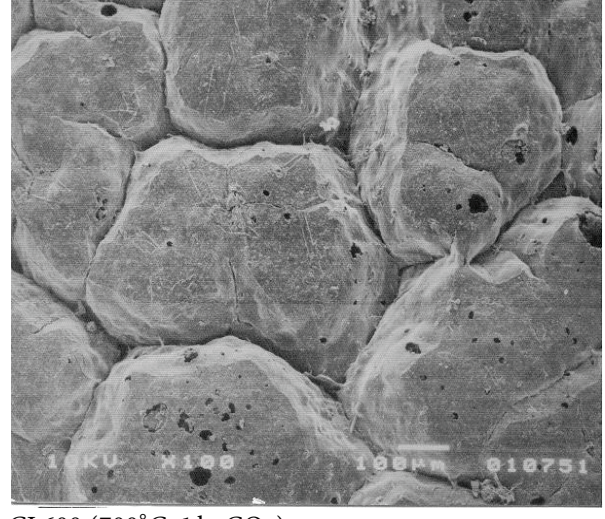

$\mathrm{CL} \overline{600}\left(700^{\circ} \mathrm{C}, 1 \mathrm{~h}, \mathrm{CO}_{2}\right)$

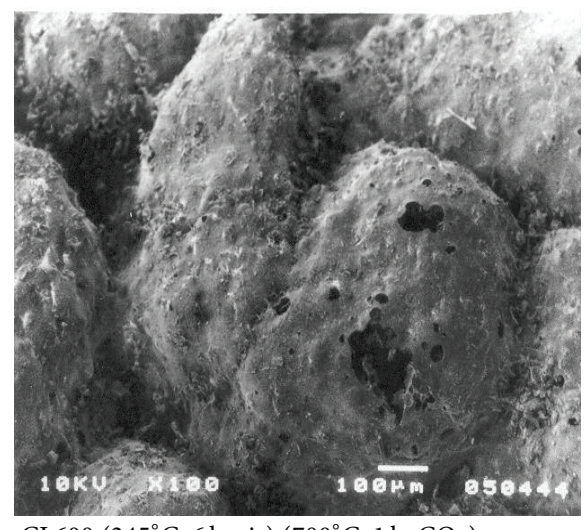

CL600 $\left(245^{\circ} \mathrm{C}, 6 \mathrm{~h}\right.$, air $)\left(700^{\circ} \mathrm{C}, 1 \mathrm{~h}, \mathrm{CO}_{2}\right)$

(b)

FIGURE 10: Micrograph of external part of sample lignin char after activation at $700^{\circ} \mathrm{C}$ during $1 \mathrm{~h}$ and under $\mathrm{CO}_{2}$ flow $(\mathrm{a})$ and pretreatment $\left(245^{\circ} \mathrm{C}, 6 \mathrm{~h}\right.$, in air) and activation (b).

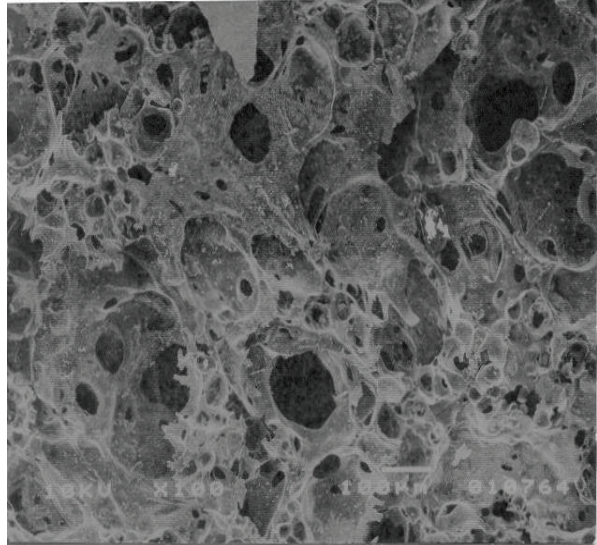

$\operatorname{CL600}\left(700^{\circ} \mathrm{C}, 1 \mathrm{~h}, \mathrm{CO}_{2}\right)$

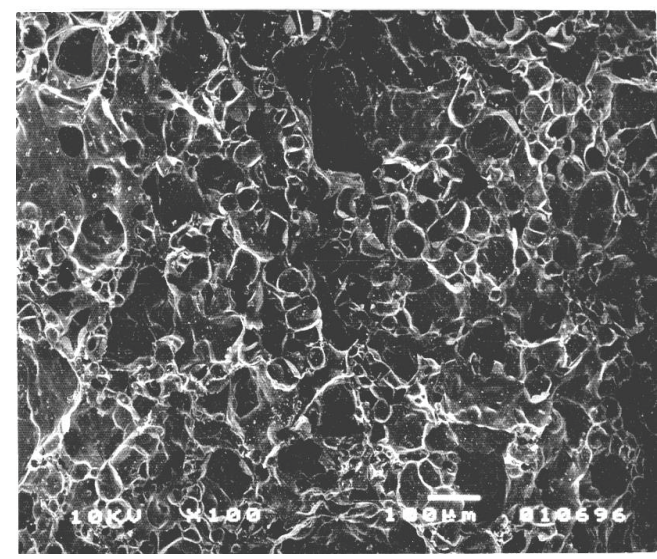

CL600 $\left(245^{\circ} \mathrm{C}, 6 \mathrm{~h}\right.$, air $)\left(700^{\circ} \mathrm{C}, 1 \mathrm{~h}, \mathrm{CO}_{2}\right)$

(a)

(b)

FIGURE 11: Micrographs of internal part of samples after activation at $700^{\circ} \mathrm{C}$ during $1 \mathrm{~h}$ and under $\mathrm{CO}_{2}$ flow (a) and pretreatment $\left(245^{\circ} \mathrm{C}, 6 \mathrm{~h}\right.$, in air) and activation (b).

Maloney et al. [13] studied the dimensional materials variations during oxidation in air. They noted that when the oxygen fixing is lower than $2 \%$, oxidation causes substantial reductions in the variations of material volume.

3.6. Microscopic Characterization. Figures 8 and 9 include the micrographs relating to the evolution, respectively, of the external and internal structure of the lignin char after pretreatment in air and activation.

The starting structure or reference is that of coal resulting from carbonization and all the comparisons will be made compared to this reference.

The micrographs of pretreated lignin char (Figure 8) show that the substance becomes more and more massive and presents the cracking in comparison with the coal. The surface change and the appearance of the cracks indicate the evolution of a thermoplastic material behavior to a thermosetting behavior. This observation was also advanced by other authors $[16,24,43]$.

The observations relating to the internal part (Figure 9) show that the preoxidation has an effect on the dimension and the number of the crazing. In fact, for times less than 9 hours, the dimension of the crazing decreases and their number increases resulting in the rearrangements caused by oxygen. However, up to 9 hours, the dimension of the crazing increases; the decomposition of the char by the oxygen would be the cause.

The preoxidized sample for 6 hours at $140^{\circ} \mathrm{C}$ presents a more dense structure than non-preoxidized sample and preoxidized sample at $245^{\circ} \mathrm{C}$ for the same treatment time; that explains the decrease in volume of the sample at $140^{\circ} \mathrm{C}$ (Figure 6). The decrease in volume corresponds to the shrinkage of the sample, which occurs during dehydration. 
Indeed, the preoxidized and activated sample (Figures 10 (b) and 11(b)) presents less macropores and more micropores compared with the non-preoxidized sample before activation (Figures 10(a) and 11(a)). The development of the microporosity in the preoxidized sample indicates, as has already been stated, that the structure is more accessible to the penetration of $\mathrm{CO}_{2}$.

Several authors [21-26] noted that the preoxidation has an effect on the development of the porous structure of the coal. The authors also stated that reoxygenation has allowed increasing the oxygen content of the coal, which implies an increase of the microporosity of char at the expense of macroporosity.

\section{Conclusion}

The aim of our study was to evaluate the effect of pretreatment on the characteristics of the activated carbon obtained from the lignin. It comes out from this work that oxidation in air has a notable influence on certain physicochemical and physical characteristics of the lignin char and on its reactivity during activation in the presence of $\mathrm{CO}_{2}$. However, the oxidation process does not affect the deformation mode acquired by the substance during its carbonization.

The duration and the temperature of oxidation have an effect on the mass, on the chemical composition of coal, and on its dimensions. The temperature and the treatment time determined to carry out the reoxygenation of the substance, without destruction, are, respectively, $245^{\circ} \mathrm{C}$ and 6 hours.

The weight loss measurements and elemental analysis indicate that oxygenation results in partial oxidation of the coal with a fixing oxygen. Oxygenation also causes a slight increase in volume of the substance.

Oxidation in air of coal improves its reactivity during activation; its specific surface area and its porous structure are modified. This would be due to a reduction in the physical limitations and the modification of the physical properties of material revealed by the microscopic characterization. The first aspect would be related to the formation of the cracks on the surface of material and the second on the evolution of material from a thermoplastic behaviour to a thermosetting behaviour.

\section{Conflict of Interests}

The authors declare that there is no conflict of interests regarding the publication of this paper.

\section{References}

[1] S. B. Lyubchik, R. Benoit, and F. Béguin, "Influence of chemical modification of anthracite on the porosity of the resulting activated carbons," Carbon, vol. 40, no. 8, pp. 1287-1294, 2002.

[2] T. A. Centeno and F. Stoeckli, "On the activation of Asturian anthracite following various pretreatments," Carbon, vol. 32, no. 8, pp. 1463-1467, 1994.

[3] J. J. Pis, J. B. Parra, G. de la Puente, F. Rubiera, and J. A. Pajares, "Development of macroporosity in activated carbons by effect of coal preoxidation and burn-off," Fuel, vol. 77, no. 6, pp. 625630, 1998.

[4] J. B. Parra, J. J. Pis, J. C. De Sousa, J. A. Pajares, and R. C. Bansal, "Effect of coal preoxidatlon on the development of microporosity in activated carbons," Carbon, vol. 34, no. 6, pp. 783-787, 1996.

[5] C. Daulan, S. B. Lyubchik, J.-N. Rouzaud, and F. Béguin, "Influence of anthracite pretreatment in the preparation of activated carbons," Fuel, vol. 77, no. 6, pp. 495-502, 1998.

[6] S. H. Lee and C. D. Lee, "Influence of pretreatment and activation conditions in the preparation of activated carbons from anthracite," Korean Journal of Chemical Engineering, vol. 18, no. 1, pp. 26-32, 2001.

[7] N. Worasuwannarak, S. Hatori, H. Nakagawa, and K. Miura, "Effect of oxidation pre-treatment at 220 to $270 \circ \mathrm{C}$ on the carbonization and activation behavior of phenolic resin fiber," Carbon, vol. 41, no. 5, pp. 933-944, 2003.

[8] Q.-B. Wang, X.-L. Zhang, D.-P. Xu, and Q.-R. Chen, "Effect of Pre-oxidation on the Properties of Crushed Bituminous Coal and Activated Carbon Prepared Therefrom," Journal of China University of Mining and Technology, vol. 17, no. 4, pp. 494-497, 2007.

[9] J. J. Pis, T. A. Centeno, M. Mahamud et al., "Preparation of active carbons from coal part I. Oxidation of coal," Fuel Processing Technology, vol. 47, no. 2, pp. 119-138, 1996.

[10] J. J. Pis, M. Mahamud, J. B. Parra, J. A. Pajares, and R. C. Bansal, "Preparation of active carbons from coal Part II. Carbonisation of oxidised coal," Fuel Processing Technology, vol. 50, no. 2-3, pp. 249-260, 1997.

[11] J. L. G. Cimadevilla, R. Álvarez, and J. J. Pis, "Influence of coal forced oxidation on technological properties of cokes produced at laboratory scale," Fuel Processing Technology, vol. 87, no. 1, pp. 1-10, 2005.

[12] J. J. Pis, A. Cagigas, P. Simón, and J. J. Lorenzana, “Effect of aerial oxidation of coking coals on the technological properties of the resulting cokes," Fuel Processing Technology, vol. 20, pp. 307-316, 1988.

[13] D. J. Maloney, R. G. Jenkins, and P. L. Walker Jr., "Lowtemperature air oxidation of caking coals. 2. Effect on swelling and softening properties," Fuel, vol. 61, no. 2, pp. 175-181, 1982.

[14] J. T. Senftle and A. Davis, "Effect of oxidative weathering on the thermoplastic and liquefaction behaviors of four coals," International Journal of Coal Geology, vol. 3, no. 4, pp. 375-381, 1984.

[15] P. A. M. Mourão, C. Laginhas, F. Custódio, J. M. V. Nabais, P. J. M. Carrott, and M. M. L. R. Carrott, "Influence of oxidation process on the adsorption capacity of activated carbons from lignocellulosic precursors," Fuel Processing Technology, vol. 92, no. 2, pp. 241-246, 2011.

[16] H. Teng, J.-A. Ho, and Y.-F. Hsu, "Preparation of activated carbons from bituminous coals with $\mathrm{CO}_{2}$ activation-influence of coal oxidation," Carbon, vol. 35, no. 2, pp. 275-283, 1997.

[17] B. Petrova, T. Budinova, N. Petrov, M. F. Yardim, E. Ekinci, and M. Razvigorova, "Effect of different oxidation treatments on the chemical structure and properties of commercial coal tar pitch," Carbon, vol. 43, no. 2, pp. 261-267, 2005.

[18] M. Jasieńko-Hałat and K. Kędzior, "Comparison of molecular sieve properties in microporous chars from low-rank bituminous coal activated by steam and carbon dioxide," Carbon, vol. 43, no. 5, pp. 944-953, 2005. 
[19] S. Cetinkaya and Y. Yürüm, "Oxidative pyrolysis of Turkish lignites in air up to $500^{\circ} \mathrm{C}$," Fuel processing technology, vol. 67, no. 3, pp. 177-189, 2000.

[20] S. Sebbahi, F. Kifani-Sahban, M. Boukallouch, A. Kifani, S. El Hajjaji, and A. Zoulalian, "Influence du pré-traitement à l'air sur lactivation du charbon obtenu à partir de la lignine," in Proceedings of the Oral Communication, 4th School of Sciences and Technology of Wood (SSTW '06), Khenifra, Morocco, November 2006.

[21] J. J. Pis, M. Mahamud, J. A. Pajares, J. B. Parra, and R. C. Bansal, "Preparation of active carbons from coal part III: activation of char," Fuel Processing Technology, vol. 57, no. 3, pp. 149-161, 1998.

[22] T. A. Centeno and F. Stoeckli, "The oxidation of an Asturian bituminous coal in air and its influence on subsequent activation by steam," Carbon, vol. 33, no. 5, pp. 581-586, 1995.

[23] T. A. Centeno, J. J. Pis, J. A. Pajares, and A. B. Fuertes, "Microporous structure of chars produced by pyrolysis of preoxidized coals," Journal of Analytical and Applied Pyrolysis, vol. 34, no. 1, pp. 13-28, 1995.

[24] T. Alvarez, A. B. Fuertes, J. Pis, J. Parra, J. Pajares, and R. Menéndez, "Influence of coal oxidation on the structure of char," Fuel, vol. 73, no. 8, pp. 1358-1364, 1994.

[25] M. Seggiani, S. Vitolo, and P. De Filippis, "Effect of preoxidation on the porosity development in a heavy oil fly ash by $\mathrm{CO}_{2}$ activation," Fuel, vol. 84, no. 12-13, pp. 1593-1596, 2005.

[26] C. Lu, S. Xu, M. Wang, L. Wei, S. Liu, and C. Liu, "Effect of preoxidation on the development of porosity in activated carbons from petroleum coke," Carbon, vol. 45, no. 1, pp. 206-209, 2007.

[27] M. E. Fernandez Ibañez, Etude de la carbonisation et l'activation de précurseurs végétaux durs et mous [Doctoral Thesis], University of Neuchâtel, Faculty of Sciences, 2002.

[28] F. Saoud, S. Sebbahi, F. Kifani-Sahban, A. Sesbou, and A. Hakam, "Contribution à l'étude de l'activation par la vapeur d'eau du charbon d'eucalyptus-effet de la préoxydation à l'air," in Oral Communication, 3th School of Sciences and Technology of Wood, SSTW- III, University Alakhawain, Ifrane, Morocco, 2005.

[29] S. Sebbahi, F. Kifani-Sahban, S. El Hajjaji, M. Boukallouch, A. Kifani, and A. Zoulalian, "Influence du pré-traitement à l'air sur l'activation du charbon obtenu à partir du bois d'eucalyptus," in Proceedings of the Moroccan-French 3rd Symposium in Molecular Chemistry, LIA, University Mohamed V, Rabat, Morocco, October 2012.

[30] F. Kifani-Sahban, A. Kifani, L. Belkbir, A. Zoulalian, J. Arauzo, and T. Cardero, "A physical approach in the understanding of the phenomena accompanying the thermal treatment of lignin," Thermochimica Acta, vol. 298, no. 1-2, pp. 199-204, 1997.

[31] F. Kifani-Sahban, Etude des aspects physiques et physicochimiques de la pyrolyse lente de l'eucalyptus et des principaux constituants du bois [Thesis], Faculty of Sciences, Rabat, Morocco, 1997.

[32] K. Friedrich, Advances in Polymer Science 52/53, Crazing in Polymers, Springer, New York, NY, USA, 1983.

[33] F. X. De Charentenay and J. B. Rieunier, Rapport Interne, Université de Technologie de Compiègne, Compiègne, France, 1979.

[34] A. Kifani and F. Sahban, Mécanique des Milieux Continus, Publibook, Paris, France, 2014.

[35] G. M. Swallowe, P. C. Dawson, T. B. Tang, and Q. L. Xu, "Thermal decomposition and micropore formation in PEK, PEEK and PES," Journal of Materials Science, vol. 30, no. 15, pp. 3853-3855, 1995.
[36] J. G. Williams, "Applications of linear fracture mechanics," in Failure in Polymers, vol. 27 of Advances in Polymer Science, pp. 67-120, Springer, Berlin, Germany, 1978.

[37] E. Plati and J. G. Williams, "Effect of temperature on the impact fracture toughness of polymers," Polymer, vol. 16, no. 12, pp. 915920, 1975.

[38] J. G. Williams, Fracture Mechanics of Polymers, Ellis Horwood, 1984.

[39] J. G. Williams, "Fracture mechanics of polymers," Polymer Engineering \& Science, vol. 17, no. 3, pp. 144-149, 1977.

[40] R. Liotta, G. Brons, and J. Isaacs, "Oxidative weathering of Illinois No.6 coal,” Fuel, vol. 62, no. 7, pp. 781-791, 1983.

[41] C. Blanco, J. F. Ferreras, J. A. Pajares, M. Mahamut, A. Pérez, and J. J. Pis, "Characterization of a spanish coal and study of the influence of oxidation time by FTIRS," Spectroscopy Letters, vol. 24, no. 6, pp. 827-836, 1991.

[42] J. F. Ferreras, C. Blanco, J. A. Pajares, M. Mahamud, and J. J. Pis, "A combined FTIR and textural study of the oxidation of a bituminous coal," Spectroscopy Letters, vol. 26, no. 5, pp. 897912, 1993

[43] M. A. Serio, S. Charpenay, R. Bassilakis, and P. R. Solomon, "Pyrolysis of phenol-formaldehyde resin: experiments and modeling," ACS Division of Fuel Chemistry, vol. 36, no. 2, p. 664, 1991. 

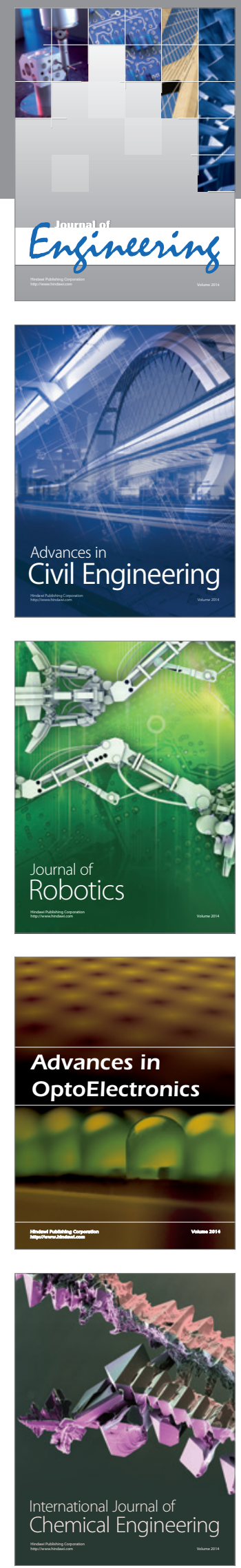

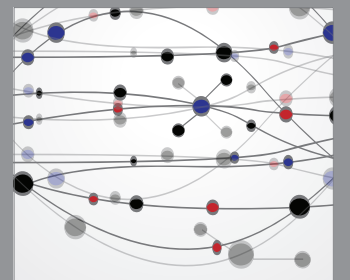

The Scientific World Journal
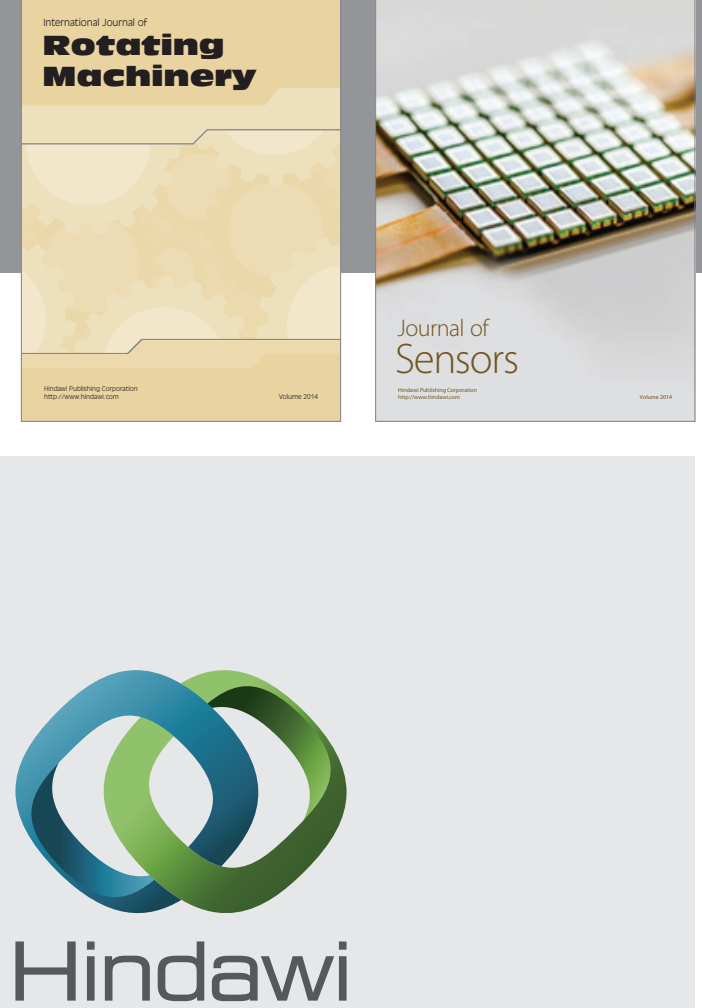

Submit your manuscripts at http://www.hindawi.com
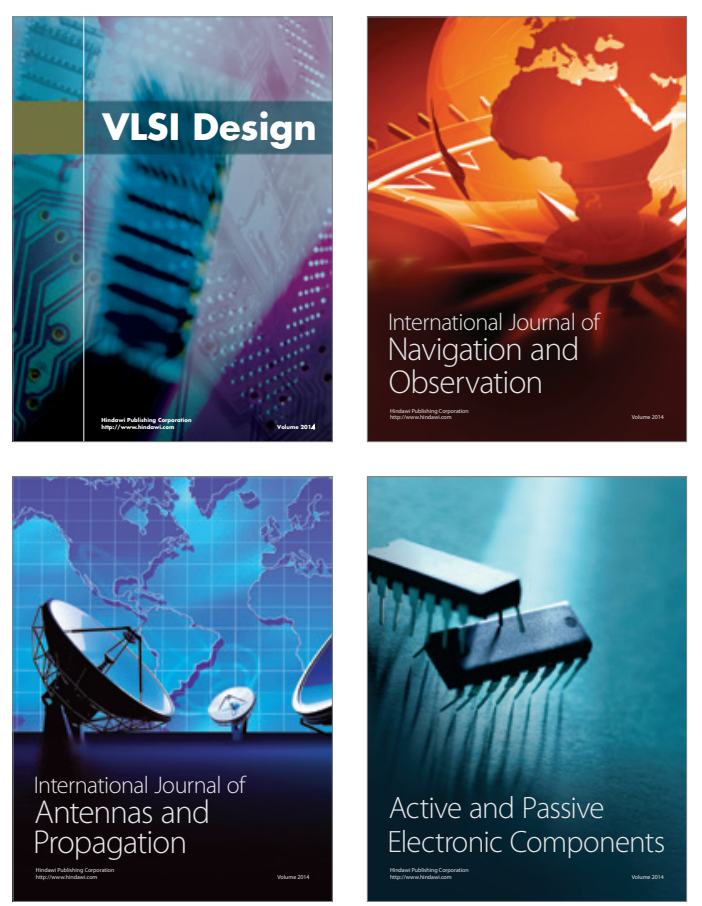
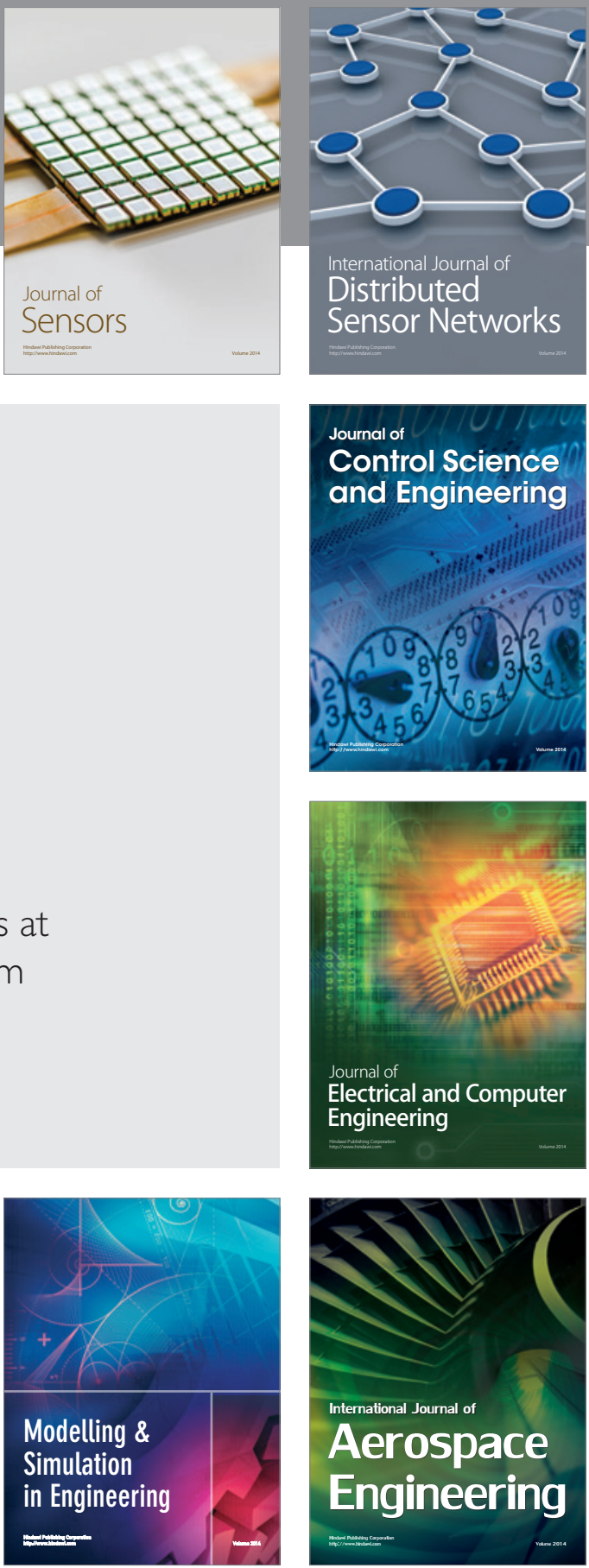

Journal of

Control Science

and Engineering
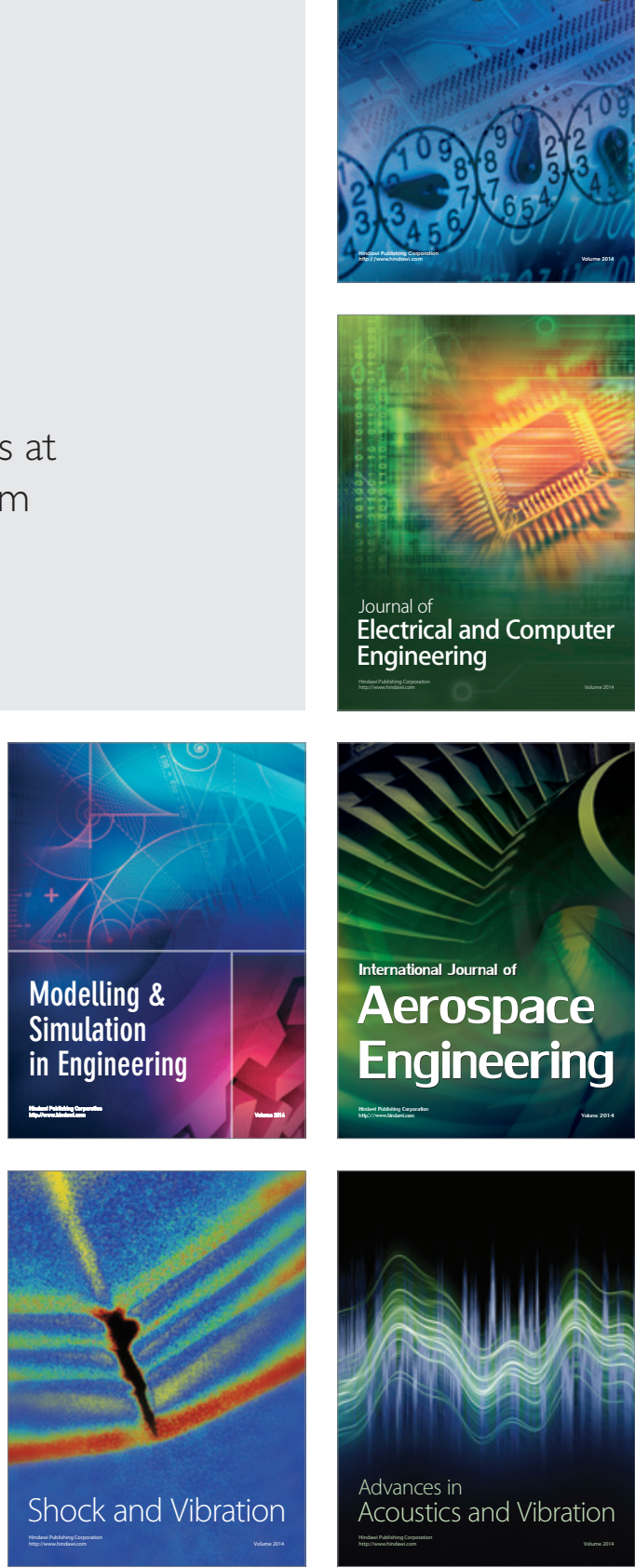